\title{
Relationship between species richness and morphodynamics in sandy beaches: what are the underlying factors?
}

\author{
Alejandro Brazeiro* \\ UNDECIMAR, Facultad de Ciencias, Iguá 4225, PO Box 10773, 11400 Montevideo, Uruguay
}

\begin{abstract}
One of the most documented generalisations in sandy beach ecology is the trend for species richness of macroinvertebrates to decrease along a morphodynamic gradient from the dissipative to the reflective condition. This widely documented pattern remains unexplained, because the responsible ecological factors and underlying biological processes are still unknown. It has been proposed that swash condition, which changes significantly along the morphodynamic gradient, is the key limiting factor underlying this biological pattern. In this study, I suggest that 2 other physical factors could also be involved: sediment grain size and erosion-accretion dynamics. This proposal is supported by a 2 yr study of 12 sandy beaches in Chile, which showed that grain size becomes coarser, erosion-accretion dynamics more intense, and swash frequency and velocity increase as morphodynamic conditions change from dissipative to reflective extremes. I propose that these 3 environmental factors, although physically interrelated, may have independent influences on different biological processes or species. I suggest therefore that the reduction of species towards the reflective extreme is caused by increasing environmental severity, which is generated by the action (of at least) the 3 physical factors mentioned above. This proposal constitutes the hypothesis of 'multicausal environmental severity', which agrees with the large interspecific variability in the life history and ecological traits of sandy beach communities, since it admits that species with different characteristics could be controlled by different limiting factors. Thus, the present hypothesis provides a more general and flexible framework for investigating the relationship between species richness and morphodynamics in sandy beaches.
\end{abstract}

KEY WORDS: Sandy beach · Species richness · Macrofauna · Morphodynamic • Swash climate · Erosion · Animal-sediment relationships

\section{INTRODUCTION}

According to their dynamic and morphological characteristics, exposed sandy beaches can be classified into several morphodynamic types (Short \& Wright 1983, Short 1996). In fact, there is a continuum of morphodynamic states, from the dissipative to the reflective extremes. Dissipative beaches are flat, gen-

*E-mail: brazeiro@fcien.edu.uy erally have fine sand, with waves breaking far from the intertidal zone and dissipating their force gradually along wide surf zones. Reflective beaches are steep, and generally have coarse sand; there is no surf zone, and waves break abruptly on the intertidal zone.

The environmental changes associated with the morphodynamic gradient seem to have relevant consequence on the intertidal macrofauna. The well-known relationship between species richness and beach morphodynamics presents strong evidence of this. In fact, one of the most supported generalisations in sandy beach ecology is the trend for species richness of 
macroinvertebrates to decrease along a morphodynamic gradient from the dissipative to the reflective condition (e.g. Defeo et al. 1992, Jaramillo \& McLachlan 1993, McLachlan et al. 1993, 1996, Brazeiro 1999a).

Although the species-morphodynamics relationship has been broadly documented, the pattern remains unexplained, since the ecological factors and biological processes involved in its generation are still unknown. However, some hypotheses have been proposed.

McLachlan (1990) proposed the 'swash control hypothesis', which suggests that the key factor limiting the distribution of species along the morphodynamic gradient is swash climate. This idea was subsequently refined by McLachlan et al. (1993) in their 'swash exclusion hypothesis', which suggests that an increasing number of species are excluded from the intertidal because the swash climate becomes harsher as the frequency of swashes and effluent-line crossings (i.e. the frequency of swashes crossing the line that separates saturated and unsaturated sands, 'the effluent line') rises. This idea is supported by 2 studies on short time scales focused on the relationship between swash climate and morphodynamics (McArdle \& McLachlan 1991, 1992). The available information to evaluate this hypothesis is insufficient. To my knowledge, only 1 test has been performed (see McLachlan et al. 1995).

The 'swash exclusion hypothesis' emphasises only one aspect of the physical environment of the intertidal habitat, the hydrodynamic, leaving aside other physical features of possible importance, such as sediment texture, availability of organic matter, and erosionaccretion dynamics. These factors are in some degree physically interrelated, and linked with beach morphodynamics (e.g., Brown \& McLachlan 1990); however, they may also have independent influences on different biological processes or species, and therefore could contribute to generating a species-morphodynamics relationship.

The communities of sandy beach invertebrates are inhabited by species of different ecological and life history traits. In these communities, species coexist that use different sources of energy (e.g., suspension feeders, deposit feeders, scavengers), have different reproductive modes (e.g., pelagic larvae, brooding), and occupy different zones of the intertidal (Brown \& McLachlan 1990, McLachlan \& Jaramillo 1995, Brazeiro \& Defeo 1996). Taking into account the large interspecific variability and the fact that many physical variables may covary with morphodynamic conditions, the idea of a unique key factor limiting the distribution of all species along the morphodynamic gradient is for me difficult to conceive. Instead, the idea of multicausality, i.e. different ecological factors limiting different species, seems more plausible.
This study constitutes a first step towards evaluating such multicausality; i.e. the search for physical factors besides swash climate that are capable of limiting the distribution of sandy beach species along a morphodynamic gradient. With this aim, the patterns in variation of several physical features of the intertidal that are of possible revelance to the macrofauna have been analysed in association with the morphodynamic gradient. Specifically, 4 types of environmental factors were considered: (1) swash dynamic; (2) sediment grain size; (3) erosion-accretion dynamics; (4) availability of organic matter.

\section{MATERIALS AND METHODS}

Study area. The study was carried out on the coast of central Chile $\left(32^{\circ} 61^{\prime}\right.$ to $\left.34^{\circ} 40^{\prime} \mathrm{S}\right)$, where 12 exposed sandy beaches covering a wide morphodynamic spectrum were investigated (Fig. 1). The coast of central Chile is very regular, almost straight, with sandy beaches fully exposed to the prevailing winds and waves and interrupted by few rocky headlands (Brattstrom \& Johanssen 1983, Santelices 1991). This is a microtidal coast, with a tidal range of 1.2 to $2.0 \mathrm{~m}$ and a semidiurnal regimen (Brattstrom \& Johanssen 1983, Santelices 1991).

The oceanographic features of this region are mainly under the influence of the Humboldt current and the counter-current of Peru-Chile (Santelices 1991, Strub et al. 1998). The interaction between the particular topographic conditions (coast orientation, shelf extent, bathymetry) and the prevailing winds (mainly SW) favours the development of upwelling in this coastal zone (Fonseca \& Farías 1987, Strub et al. 1998). Surface water temperature varies seasonally between 12 and $17^{\circ} \mathrm{C}$, and salinity fluctuates around 35 (Santelices 1991, Strub et al. 1998).

Sampling procedure. The 12 sandy beaches selected (Fig. 1) were visited during low tide every 2 mo from April 1997 to November 1998. On the 10 sampling occasions, the following physical variables were measured at each beach: (1) beach slope; (2) mean grain size; (3) sediment sorting; (4) height and period of modal wave (5) swash velocity; (6) swash frequency ; (7) effluent line crossings; (8) concentration of particulate organic matter in water; (9) percentage of organic matter in the sediment). With the exception of swash velocity and percentage of organic matter in the sediment (see below), the variables were measured on each sampling occasion. Table 1 shows the nomenclature used to describe the physical variables measured.

One transect per beach was randomly placed, to generate beach profiles by Emery's method (Emery 1961), in order to estimate the beach slope $(S)$ : 


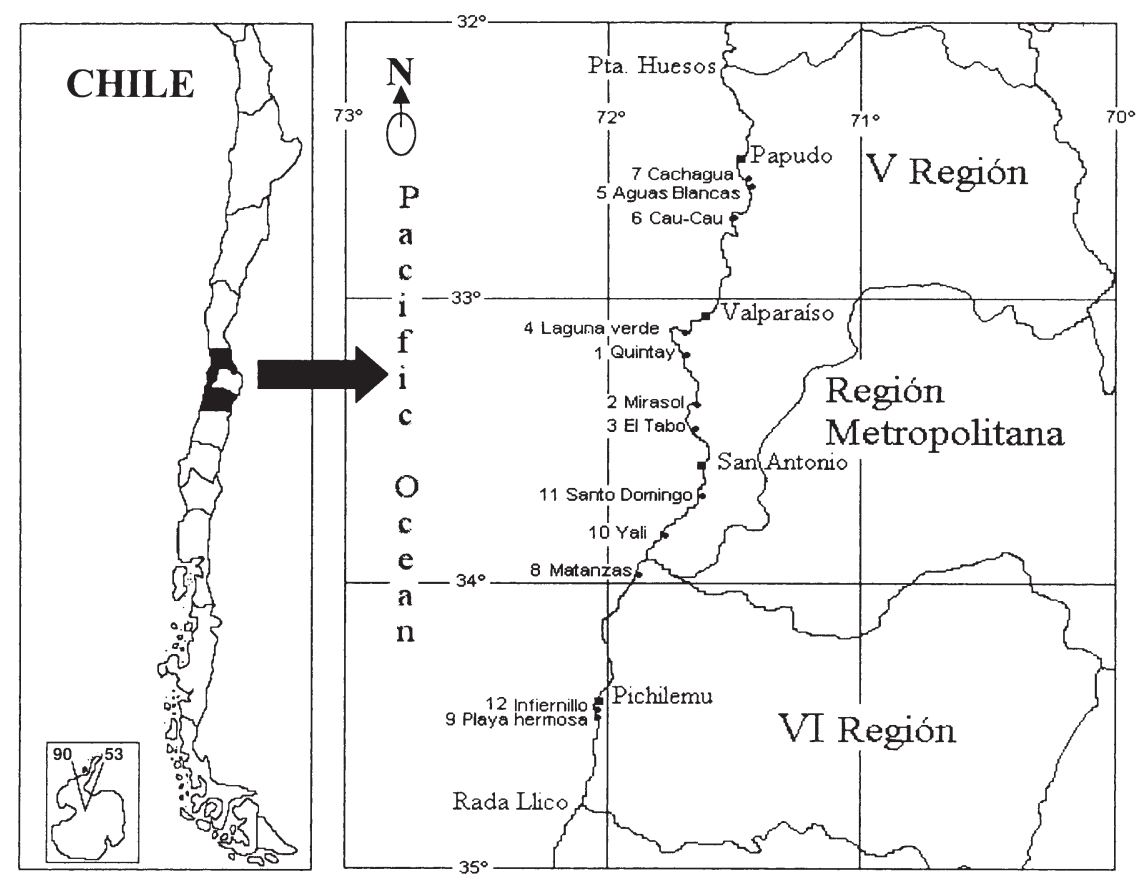

Fig. 1. Study area, showing locations of the 12 sandy beaches surveyed in central Chile

$$
S=\frac{\sum_{i=1}^{i=k} \frac{h_{i}}{D_{i}} \times 100}{k}
$$

where $h_{i}$ is the difference in height between 2 consecutive sampling points (pair $i$ ) along the transect, $D_{i}$ is the horizontal distance between these 2 sampling points $(2 \mathrm{~m})$, and $k$ is the number of pairs of consecutive sampling points -1 .

For grain-size analysis, 3 sediment samples were collected, 1 each from the upper, middle and lower intertidal. The sorting of sands by grain size was carried out with a settling tube (Emery 1938), and the calculation of statistics (mean grain size and sorting) was performed according to the momentum method (Seward-Thompson \& Hails 1973).

Modal wave height was determined by measuring breaking waves with graduated poles against the horizon ( $\mathrm{n}=9$ ). Wave period was estimated as the time interval between consecutive breaking waves, measured with a watch stop $(\mathrm{n}=9)$.

Swash conditions of the 12 sandy beaches were characterised during low tides. Swash period was measured as the time interval between consecutive swashes reaching a fixed point in the middle of the swash zone $(n=9)$. Swash frequency was then calculated as the inverse of swash period. Swash velocity was measured 4 times (May, July, September and November 1998) at each of the 12 beaches. The velocity of 20 randomly selected swashes were measured with a Bell \& Denny
(1994) dynamometer and the calibration equation of Castilla et al. (1998). To estimate the effluent line crossings, I measured the time interval between consecutive swashes crossing the effluent line (i.e. the line separating the saturated and unsaturated sands) $(\mathrm{n}=9)$.

Triplicate water samples of 11 were taken to determine the concentration of particulate organic matter (POM). Water samples were filtered in situ with $0.7 \mu \mathrm{m}$ Whatman $(\mathrm{GF} / \mathrm{F})$ filters. The samples were stored at $-20^{\circ} \mathrm{C}$ until the organic fraction was determined in the laboratory by the weight-loss method, using temperatures of $60^{\circ} \mathrm{C}$ for $48 \mathrm{~h}$ and $500^{\circ} \mathrm{C}$ for $6 \mathrm{~h}$, to dry and burn the samples respectively.

On 2 sampling occasions (September and November 1998), triplicate sediment samples were collected from the upper, middle and lower intertidal to determine their organic matter content. The sediment samples were refrigerated $\left(-20^{\circ} \mathrm{C}\right)$ until determination of their organic content by the weight-loss method, using the same protocol described above for the estimation of POM.

From the average wave height $(H b)$, wave period $(T)$ and sand-fall velocity $(W)$, estimated for the whole study period, Dean's dimensionless parameter $(\Omega)$ (Short \& Wright 1983) was calculated using the following equation:

$$
\Omega=\frac{H b}{W \cdot T}
$$

The values of $W$ were estimated using the mean grain-size estimations and the conversion tables given by Gibbs et al. (1971). 
The intertidal communities at macroinvertebrates the 12 beaches selected were also sampled every 2 mo, from April 1997 to November 1998. Following a systematic approach, 50 sampling units (SUs) were taken per locality and sampling period. For the purpose of this study, a sandy beach locality was defined as a sandy coastal belt of $100 \mathrm{~m}$ in length, in which the along-beach variability of physical characteristics was assumed to be relatively low. Along 10 transects $(10 \mathrm{~m}$ apart), 5 SUs per transect were obtained, each with a core of $0.02 \mathrm{~m}^{2}$ and $30 \mathrm{~cm}$ in depth. The first SU was collected around the drift line (1 to $3 \mathrm{~m}$ above), the second and third between the drift and effluent lines, and the fourth and fifth under the effluent line. The collected material was sieved through $1 \mathrm{~mm}$ mesh, and the retained organisms were stored in $10 \%$ formalin for identification and counting in the laboratory.

Data analysis. For each physical variable, the mean and standard deviation for the whole study period was calculated per location. The means were used to estimate the prevalent physical conditions at each beach, while the standard deviations were used to indicate the temporal variability (see Table 1).

The spatial variability (i.e. among beaches) of the means and standard deviation of each physical variable was analysed separately. The relationship between the morphodynamic state of the beach and the physical variables measured was estimated by the Spearman's rank correlation coefficient $\left(\mathrm{r}_{\mathrm{S}}\right)$. Two indexes of the morphodynamic condition of beaches were used, Dean's parameter and the mean slope of the beach.

In order to assess the adequacy of sampling effort to estimate the local species richness, species-area curves

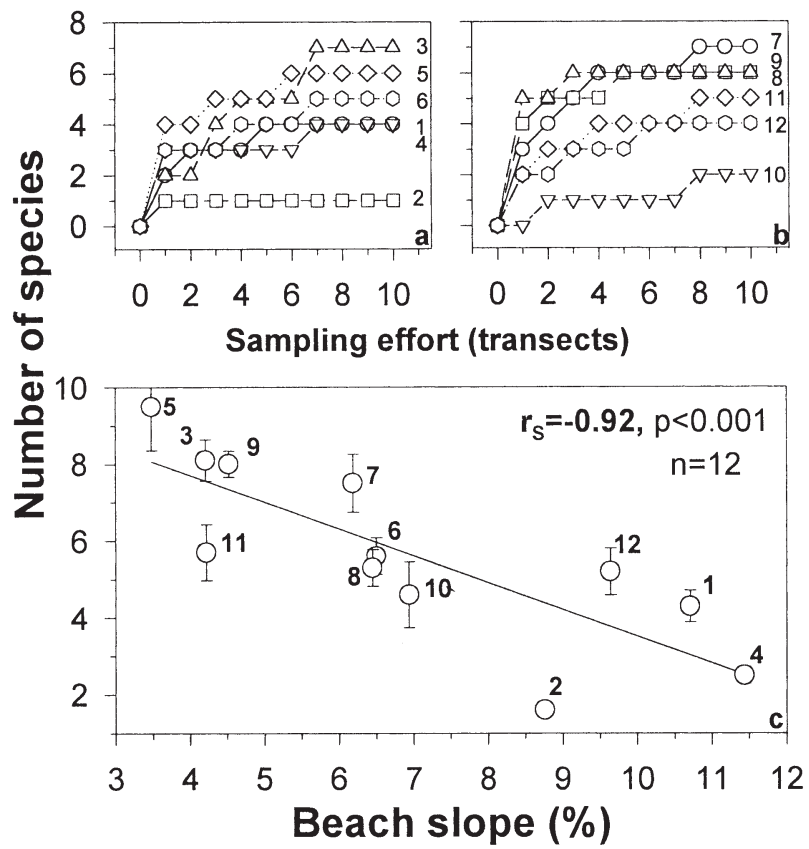

Fig. 2. $(a, b)$ Species-area curves for 12 sandy beaches of central Chile during April 1997. Each curve represents the average of 100 curves generated by randomising the cumulative order of transects. Numbers following curves indicate beach numbers (see Fig. 1). (c) Relationship between mean (SE) species richness and mean beach slope, showing Spearman's rank correlation coefficient $\left(\mathrm{r}_{\mathrm{S}}\right)$, associated probability $(\mathrm{p})$, and number of replicates (n)

were made for each of the 12 beaches. The curves were generated by cumulating species by transects, and not by sampling units as in Jaramillo et al. (1995). I preferred the cumulative procedure because sandy

Table 1. Nomenclature of the principal physical variables measured in this study

\begin{tabular}{|lrl|}
\hline Type & Variable & \multicolumn{1}{c|}{ Variable description } \\
\hline Morphodynamic index & $\Omega$ & Dean's parameter (for the whole period) \\
& S-m & Mean beach slope $(\%)$ \\
Sedimentology & Mz-m & Mean grain size $(\mu \mathrm{m})$ \\
& So-m & Sediment sorting $(\mu \mathrm{m})$ \\
Swash climate & Sw-m & Mean swash frequency $\left(\mathrm{min}^{-1}\right)$ \\
& Ef-m & Mean effluent line crossings $\left(\min ^{-1}\right)$ \\
& Ve-m & Mean swash velocity $\left(\mathrm{m} \mathrm{s}^{-1}\right)$ \\
Organic content & POM-m & Mean particulate organic matter in water $\left(\mathrm{mg} \mathrm{l}^{-1}\right)$ \\
& OMS-m & Mean organic matter in sediment $(\%)$ \\
Temporal variability of: & Sw-s & Standard deviation of swash frequency $\left(\mathrm{min}^{-1}\right)$ \\
Swash climate & Ef-s & Standard deviation of effluent line crossings $\left(\mathrm{min}^{-1}\right)$ \\
& Ve-s & Standard deviation of swash velocity $\left(\mathrm{m} \mathrm{s}^{-1}\right)$ \\
Organic content & SOM-s & Standard deviation of particulate organic matter in water $\left(\mathrm{mg} \mathrm{l}^{-1}\right)$ \\
& OMS-s & Standard deviation of organic matter in sediment $(\%)$ \\
Geomorphology & S-d & Standard deviation of beach slope $(\%)$ \\
& Mz-d & Standard deviation of grain size $(\mu \mathrm{m})$ \\
\end{tabular}


beach macrofauna show evident zonation patterns along the intertidal (e.g., McLachlan \& Jaramillo 1995, Brazeiro \& Defeo 1996). The sampling unit does not provide a random sample of the whole community, because the probability of capture varies among species depending on their intertidal location. The use of transects solves this problem, since a species probability of capture is only a function of its abundance. For each locality, 100 curves were generated in random (with replacement) cumulative order, and the average curves were used to evaluate the degree of saturation.

\section{RESULTS}

\section{Species-morphodynamics relationship}

The average species-area curves for the 12 sandy beach communities showed evidence of saturation on each of the 10 sampling occasions. The species-area curves for April 1997 are presented in Fig. 2a,b. In general, 8 transects (pooled area $0.8 \mathrm{~m}^{2}$ ) were sufficient to adequately estimate the species richness of the local communities surveyed.

The average species richness for the whole study period decreased significantly with increasing mean beach slope (Fig. 2c). The mean number of species in the local communities varied from a maximum of 9.5 at the dissipative Site 5, to a minimum of 1.6 at the reflective Site 2 . The negative correlation between species richness and beach slope was observed on all sampling occasions, being statistically significant in 8 cases (Table 2). Negative non-significant correlations were observed in August 1997 and February 1998.

\section{Mean physical variations along morphodynamic gradient}

The 12 sandy beaches covered a wide morphodynamic spectrum ( $\Omega$ : 1.0 to $5.3, \mathrm{~S}-\mathrm{m}: 3.5$ to $11.4 \%$ ), embracing 5 of the 6 categories in the classification system of Short \& Wright (1983). On average, Beach 2 was reflective $(\Omega<1)$, Beaches 4 and 6 were Intermediate Type I $(1<\Omega<2)$, Beach 10 was Intermediate Type II $(2<\Omega<2.5)$, Beaches 1 and 12 were Intermediate Type III $(2.5<\Omega<3.5)$, and Beaches $3,5,7,8,9$ and 11 were Intermediate Type IV $(3.5<\Omega<6)$ (Table 3).

With the exception of sediment sorting (So-m) and particulate organic matter (POM-m), the mean values of the physical variables measured varied widely (i.e. $\mathrm{CV}>10 \%$ ) among beaches (Table 3 ). Mean grain size $(\mathrm{Mz}-\mathrm{m})$, swash frequency $(\mathrm{Sw}-\mathrm{m})$, effluent-line crossings (Ef-m) and swash velocity (Ve-m) were signifi-
Table 2. Correlation analyses between local species richness and beach slope on 10 sampling occasions. Spearman's rank correlation coefficients $\left(r_{s}\right)$, associated probabilities $(p)$, and number of replicates (n) are presented for each sampling occasion. Bold values: significant correlations $(p<0.05)$

\begin{tabular}{|lccc|}
\hline Sampling month & $\mathrm{r}_{\mathrm{S}}$ & $\mathrm{p}$ & $\mathrm{n}$ \\
\hline June 97 & $\mathbf{- 0 . 6 5}$ & $\mathbf{0 . 0 2 2}$ & 12 \\
August 97 & -0.38 & 0.223 & 12 \\
October 97 & $\mathbf{- 0 . 6 3}$ & $\mathbf{0 . 0 2 9}$ & 12 \\
December 97 & $\mathbf{- 0 . 8 0}$ & $\mathbf{0 . 0 0 2}$ & 12 \\
February 98 & -0.49 & 0.108 & 12 \\
April 98 & $\mathbf{- 0 . 6 4}$ & $\mathbf{0 . 0 2 6}$ & 12 \\
June 98 & $\mathbf{- 0 . 7 2}$ & $\mathbf{0 . 0 1 2}$ & 11 \\
August 98 & $\mathbf{- 0 . 9 0}$ & $\mathbf{< . 0 0 1}$ & 10 \\
October 98 & $\mathbf{- 0 . 6 5}$ & $\mathbf{0 . 0 2 2}$ & 12 \\
December 98 & $\mathbf{- 0 . 7 4}$ & $\mathbf{0 . 0 0 6}$ & 12 \\
\hline
\end{tabular}

cantly correlated with the morphodynamic indexes (Table 4), but mean sediment sorting (So-m), particulate organic matter (POM-m) and organic matter in sediment (OMS-m) were independent of morphodynamic state (Table 4).

Although the morphodynamic indexes $\Omega$ and S-m were significantly correlated $\left(\mathrm{r}_{\mathrm{S}}=-0.85, \mathrm{p}<0.001\right)$, they did not predict the physical environment of the beach in the same way. Dean's parameter was the best predictor of $\mathrm{Mz}$, whereas S-m better described the variability of swash conditions among beaches (Sw-m, Ef-m and Ve-m; Table 4). In general, as the morphodynamic conditions changed from the dissipative extreme towards the reflective extreme, i.e. from gentle to steep slopes, the sediment became coarser, the swashes more frequent and faster, and swashes crossed the effluent line with more frequency (Fig. 3). Along the slope range considered, $\mathrm{Mz}$ increased from almost 200 to $900 \mu \mathrm{m}$ (Fig. 3a). On average, the frequency of swashes and effluent-line crossings in the reflective extreme, duplicate and triplicate respectively, the normal values under dissipative conditions, while the swash velocity augmented from 0.5 to $0.8 \mathrm{~m} \mathrm{~s}^{-1}$ (Fig. 3b,c).

\section{Temporal physical variations along morphodynamic gradient}

The temporal variability (measured by standard deviations) of swash conditions, with the exception of Ve-s, was clearly independent of beach morphodynamics (Table 5). The standard deviation of swash velocity tended marginally to increase $\left(\mathrm{r}_{\mathrm{S}}=0.50, \mathrm{p}=\right.$ 0.09) with increasing mean beach slope, from almost 0.06 to $0.12 \mathrm{~m} \mathrm{~s}^{-1}$ (Fig. 4a). The temporal variability of $\mathrm{Mz}$ tended to increase almost 3 times between the dis- 
sipative and reflective extremes, and was equally predicted by $\Omega$ and S-m (Fig. 4b, Table 5). Sediment sorting varied independently of beach morphodynamics (Table 5). The temporal variability of the beach slope was significantly correlated with the mean beach slope (Table 5). Beach profiles, and therefore their slopes, were more erratic under reflective conditions, almost 4 times more variable than in the dissipative extreme (Fig. 4c,d,e).

The concentration of POM in the water tended to be more variable over time as $\Omega$ increased, i.e. as morphodynamic conditions became more dissipative (Table 5, Fig. 5). On average, POM increased towards the dissipative extreme from 0.24 to $0.36 \mathrm{mg} \mathrm{l}^{-1}$ (50\%) (Fig. 5).

\section{DISCUSSION AND CONCLUSIONS}

\section{Species-morphodynamics pattern}

The species richness of sandy intertidal assemblages of central Chile decreased significantly along a morphodynamic gradient, from dissipative to reflective extremes. This pattern was temporally consistent over 20 mo observation. Likewise, this pattern in Chile seems to be independent of spatial scale since it has been detected on both geographic $(2000 \mathrm{~km})$ and regional (200 km) scales (Brazeiro 1999a).

The findings reported here are not surprising. In fact, the trend of decreasing species richness from dissipa-

Table 3. Average physical traits of 12 sandy beaches of central Chile. Means (SE) for the whole study period, together with global mean, standard deviation and coefficient of variation for each variable are given. Variables are abbreviated as in Table 1.

\begin{tabular}{|lccccccccc|}
\hline Beach & $\Omega$ & $\begin{array}{c}\text { S-m } \\
(\%)\end{array}$ & $\begin{array}{c}\text { Mz-m } \\
(\mu \mathrm{m})\end{array}$ & $\begin{array}{c}\text { So-m } \\
(\mu \mathrm{m})\end{array}$ & $\begin{array}{c}\text { Sw-m } \\
\left(\mathrm{min}^{-1}\right)\end{array}$ & $\begin{array}{c}\text { Ef-m } \\
\left(\mathrm{min}^{-1}\right)\end{array}$ & $\begin{array}{c}\text { Ve-m } \\
\left(\mathrm{m} \mathrm{s}^{-1}\right)\end{array}$ & $\begin{array}{l}\text { POM-m } \\
\left(\mathrm{mg} \mathrm{l}^{-1}\right)\end{array}$ & \multicolumn{1}{c|}{$\begin{array}{c}\text { OMS-m } \\
(\%)\end{array}$} \\
\hline (1) Quintay & 3.0 & $10.7(1.1)$ & $538.3(46.9)$ & $700.6(34.3)$ & $5.2(0.3)$ & $3.3(0.3)$ & $0.79(0.03)$ & $6.72(0.12)$ & $0.30(0.009)$ \\
(2) Mirasol & 1.0 & $8.8(0.6)$ & $959.1(53.5)$ & $746.2(28.5)$ & $5.1(0.3)$ & $3.6(0.4)$ & $0.89(0.02)$ & $6.88(0.11)$ & $0.24(0.036)$ \\
(3) El Tabito & 5.3 & $4.2(0.6)$ & $319.2(14.5)$ & $706.0(24.3)$ & $3.0(0.3)$ & $1.2(0.4)$ & $0.72(0.03)$ & $6.79(0.07)$ & $0.30(0.028)$ \\
(4) L. Verde & 1.4 & $11.4(0.6)$ & $894.9(69.4)$ & $752.6(13.7)$ & $5.9(0.3)$ & $3.5(0.2)$ & $0.79(0.04)$ & $6.97(0.10)$ & $0.31(0.043)$ \\
(5) A. Blancas & 5.2 & $3.5(0.3)$ & $252.9(7.1)$ & $692.3(37.4)$ & $3.0(0.3)$ & $0.8(0.1)$ & $0.72(0.03)$ & $6.68(0.09)$ & $0.51(0.063)$ \\
(6) Cau-Cau & 1.5 & $6.5(0.6)$ & $474.6(44.2)$ & $729.9(23.2)$ & $5.2(0.3)$ & $1.5(1.5)$ & $0.74(0.02)$ & $6.90(0.15)$ & $0.49(0.004)$ \\
(7) Cachagua & 4.5 & $6.2(0.5)$ & $311.7(9.1)$ & $737.4(29.7)$ & $3.7(0.4)$ & $1.3(0.2)$ & $0.74(0.03)$ & $6.61(0.12)$ & $0.47(0.061)$ \\
(8) Matanzas & 3.5 & $6.5(0.5)$ & $316.6(9.9)$ & $755.5(24.5)$ & $3.5(0.2)$ & $0.9(0.1)$ & $0.65(0.01)$ & $6.17(0.09)$ & $0.65(0.004)$ \\
(9) P. Hermosa & 5.0 & $4.5(0.4)$ & $313.2(10.3)$ & $742.5(29.0)$ & $3.1(0.3)$ & $1.0(0.2)$ & $0.70(0.02)$ & $6.54(0.07)$ & $0.72(0.137)$ \\
(10 Yali & 2.1 & $6.9(0.7)$ & $449.1(105.7)$ & $731.7(25.5)$ & $4.2(0.4)$ & $1.8(0.5)$ & $0.74(0.03)$ & $6.58(0.09)$ & $0.63(0.091)$ \\
(11) S. Domingo & 4.6 & $4.2(0.3)$ & $264.8(5.6)$ & $767.0(20.8)$ & $3.3(0.3)$ & $1.1(0.3)$ & $0.63(0.02)$ & $6.71(0.11)$ & $0.55(0.016)$ \\
(12) Infiernillo & 3.1 & $9.6(1.0)$ & $460.3(23.5)$ & $775.4(10.5)$ & $4.7(0.3)$ & $2.8(0.3)$ & $0.89(0.03)$ & $6.55(0.09)$ & $0.62(0.085)$ \\
Mean & 3.1 & 6.9 & 462.9 & 736.4 & 4.1 & 1.9 & 0.57 & 6.67 & 0.48 \\
SD & 1.2 & 2.7 & 235.4 & 26.0 & 1.0 & 1.1 & 0.06 & 0.21 & 0.16 \\
CV (\%) & 49.1 & 38.6 & 50.9 & 3.5 & 24.8 & 56.8 & 10.3 & 3.2 & 33.4 \\
\hline
\end{tabular}

Table 4. Correlation analysis between morphodynamic indexes ( $\Omega$ and S-m) and means of the physical variables measured, showing Spearman's rank correlation coefficients and associated probabilities (in parentheses). Variables abbreviated as in Table 1. Bold values: significant correlations $(p<0.05)$

\begin{tabular}{|c|c|c|c|c|c|c|c|}
\hline Variable & $\mathrm{Mz}-\mathrm{m}$ & So-m & Sw-m & Ef-m & Ve-m & POM-m & OMS-m \\
\hline$\Omega$ & $-0.84(<0.001)$ & $-0.23(0.47)$ & $-0.92(<0.001)$ & $-0.82(<0.001)$ & $-0.71(0.058)$ & $-0.43(0.16)$ & $0.30(0.35)$ \\
\hline S-m & $0.77(<0.001)$ & $0.25(0.43)$ & $0.90(<0.001)$ & $0.86(<0.001)$ & $0.80(0.002)$ & $0.27(0.40)$ & $-0.25(0.44)$ \\
\hline
\end{tabular}

Table 5. Correlation analysis between morphodynamic indexes ( $\Omega$ and S-m) and temporal variability (standard deviation) of physical variables measured, showing Spearman's rank correlation coefficients and associated probabilities (in parentheses). Variables abbreviated as in Table 1. Standard deviation of OMS was not analysed because only 2 temporal replicates were available. Bold values: significant correlations $(p<0.05)$

\begin{tabular}{|c|c|c|c|c|c|c|c|}
\hline Variable & S-s & Mz-s & So-s & Sw-S & Ef-s & Ve-s & POM-s \\
\hline$\Omega$ & $-0.45(0.14)$ & $-0.78(0.003)$ & $0.26(0.42)$ & $-0.12(0.71)$ & $-0.34(0.29)$ & $-0.23(0.47)$ & $0.61(0.036)$ \\
\hline S-m & $0.65(0.02)$ & $0.78(0.003)$ & $-0.30(0.34)$ & $0.06(0.85)$ & $0.18(0.59)$ & $0.50(0.09)$ & $-0.20(0.53)$ \\
\hline
\end{tabular}




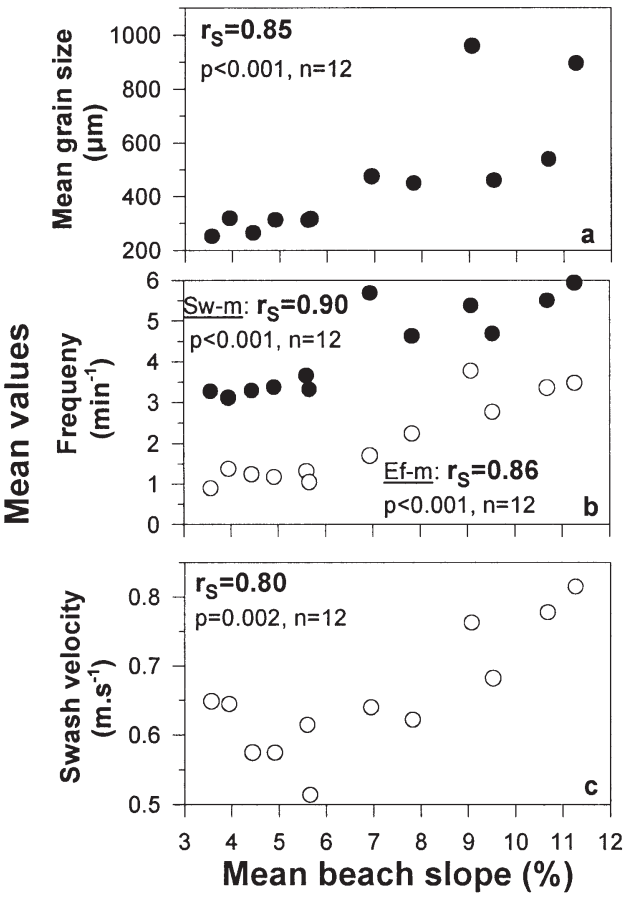

Fig. 3. Relationship between mean beach slope and mean (a) grain size, (b) swash frequency, Sw-m, and effluent-line crossings, Ef-m, and (c) swash velocity, showing Spearman's rank correlation coefficient $\left(r_{S}\right)$, associated probability $(p)$, and number of replicates (n)

tive to reflective morphodynamic conditions is one of the most documented generalisations in sandy beach ecology (e.g., Brown \& McLachlan 1990, Defeo et al. 1992, Jaramillo \& McLachlan 1993, McLachlan et al. 1993, 1996, Brazeiro 1999a).

It has been shown that the pattern occurs and is temporally and spatially consistent. The question remains as to how it is generated. An important step towards answering this question is the identification of the underlying controlling factors. In an attempt to identify possible limiting factors, the capacity of several environmental variables to limit the distribution of species along the morphodynamic gradient is discussed in the following subsections, and a new hypothesis explaining the species-morphodynamics relationship is proposed.

\section{Swash climate}

The average frequency and velocity of swashes, and the frequency of swashes crossing the effluent line, increase significantly from the dissipative to the reflective extremes. This trend, which is based on averages summarising long-term data, agrees with 2 previous studies on sandy beaches in South Africa and the USA (McArdle \& McLachlan 1991, 1992).
Although both morphodynamic indexes ( $\Omega$ and S-m) were significantly correlated, this work and the studies of McArdle \& McLachlan $(1991,1992)$ have shown that beach slope better predicts the spatial variability of swash features than does Dean's parameter. Thus,

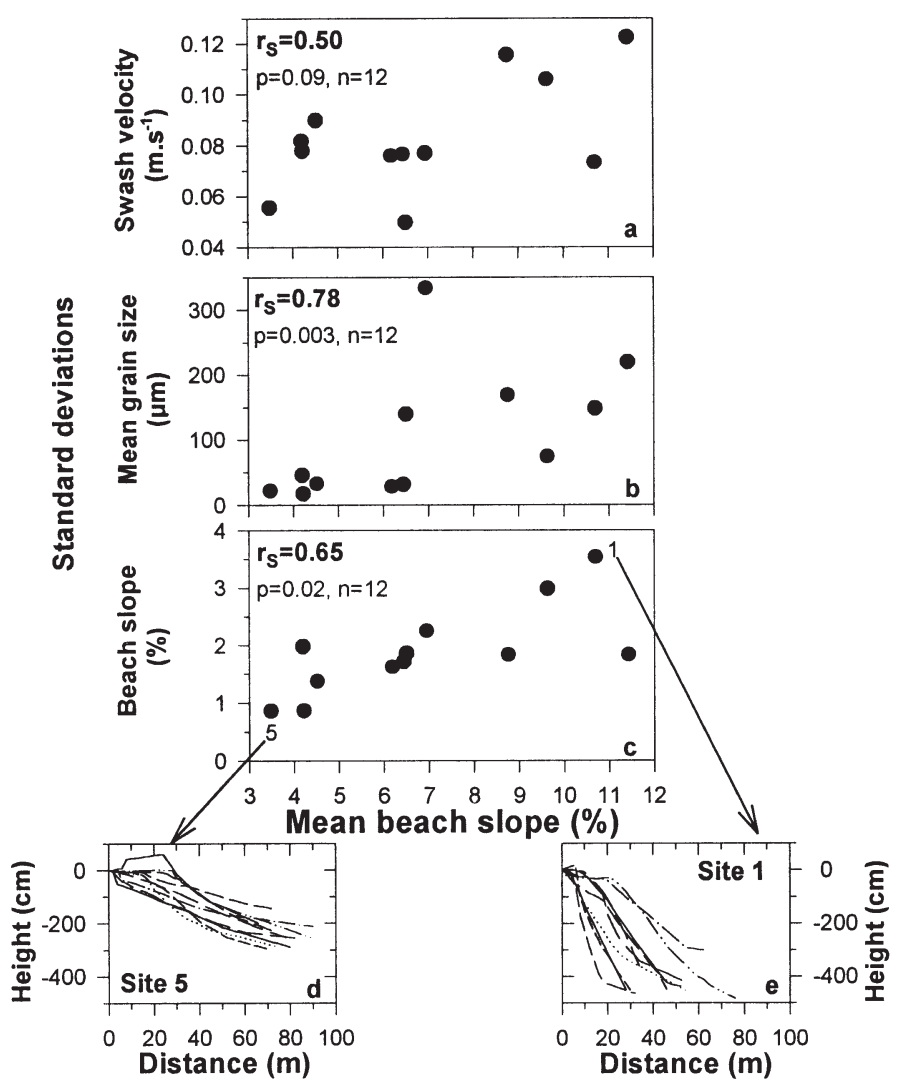

Fig. 4. Relationship between mean beach slope and temporal variability (standard deviations) of (a) swash velocity, (b) grain size, and (c) beach slope, showing Spearman's rank correlation coefficient $\left(\mathrm{r}_{\mathrm{S}}\right)$, associated probability $(\mathrm{p})$, and number of replicates (n). (d,e) Beach profiles for Sites 5 and 1, respectively, measured on the 10 sampling occasions

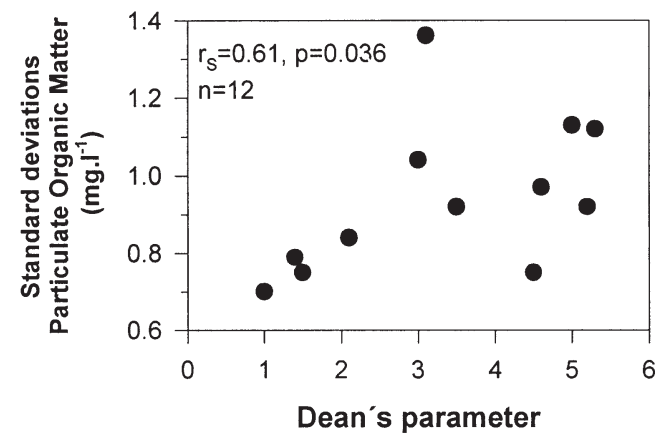

Fig. 5. Relationship between Dean's parameter and temporal variability (standard deviation) of particulate organic matter in water, showing Spearman's rank correlation coefficient $\left(r_{S}\right)$, associated probability $(p)$, and number of replicates $(n)$ 
beach slope is a good indicator of the environmental characteristics of the intertidal habitat.

The possible effects of swash climate for the intertidal macrofauna have been previously discussed by McLachlan and associates (McLachlan 1990, McArdle \& McLachlan 1991, McLachlan et al. 1993), who proposed that the swash climate of reflective beaches could negatively affect the macrofauna through 3 mechanisms: (1) reduction of feeding time through frequent but short swashes; (2) increased risk of animals being removed from the substratum with increasing swash frequency; and (3) increased risk of animals being swept and stranded above the effluent line (where they are unable to burrow: see Brown 1983), with increasing frequency of effluent-line crossings. Swash climate may therefore play an important role in deciding the species-morphodynamics pattern.

\section{Sediment type}

The particle size of the sediment varied significantly along the morphodynamic gradient, tending to increase towards the reflective extreme. The magnitude of variation in mean grain size was very large, increasing almost 5 times along a slope range of $8 \%$. Several authors (e.g., McLachlan et al. 1981, Brown \& McLachlan 1990, McLachlan 1990, Defeo et al. 1992, Borzone et al. 1996) have documented similar patterns. However, McLachlan (1990) and McLachlan et al. (1993) may have underrated the eventual role of grain size in the control of species richness along the morphodynamic gradient. Based on the experimental results of Brown (1983) and Jaramillo (1987), these authors suggested that sand type would not be a limiting factor because most sandy beach animals can exist in a wider range of particle sizes than they encounter in nature.

There is however experimental evidence that demonstrates active sediment selection in 2 species of isopods (Defeo et al. 1997), suggesting that even though these species can survive over wide sediment ranges, they do have optimum ranges. For example, behavioural functions that are important for individuals living in sandy intertidal habitats, such as burrowing and locomotion (Brown \& McLachlan 1990), may be affected by the mean grain size of the sediment. Experimental studies have demonstrated that coarse sediments have negative effects on the burrowing ability of sandy beach species, e.g., bivalves (Alexander et al. 1993), cirolanid isopods (Yannicelli 1999), and anomuran crabs (Brazeiro 1999b). Likewise, a recent study by McLachlan (1996) on the effects of disposal of diamond-mine tailings on sandy beach fauna in Namibia indicated that grain size can affect species richness. McLachlan (1996) reported that coarse sand in the tailings increased the mean grain size of some beaches, changing their morphodynamic state from dissipative to intermediate, and decreasing species richness and abundance. McLachlan (1996) suggested that the loss of species following the tailings disposal could, among factors, be due to (1) the increased sandparticle size restricting body size, burrowing rates and others functions, and (2) the change in the beach state and concomitant changes in the swash regime.

As the ability of a sandy beach animal to avoid a predator or severe swash depends mainly on its burrowing rate, it is possible that sediment type could alter the mortality rates of some species and consequently limit their distribution. Therefore, sediment grain size may be at least partially responsible for the pattern of variation in species richness along the morphodynamic gradient.

\section{Erosion and accretion dynamics}

The substratum of sandy beaches is highly unstable, since sand is continuously transported to the beach during accretion periods, and removed from the beach during erosion events. The movements of the sand alter the sediment grain size and the beach profile and therefore its slope (Araya-Vergara 1986). The process of accretion is normally associated with a reduction in mean particle size and with a flattening of the beach slope, whereas erosion produces the reverse (ArayaVergara 1986). Therefore, the temporal variability of the slope and mean grain size of a given beach could be used as an index of the magnitude of its erosionaccretion dynamics.

The present study found that the temporal variability in beach slope and mean grain size (as measured by their standard deviations) tended to increase along a morphodynamic gradient from the dissipative to the reflective extremes. This indicates that the magnitude of erosion-accretion dynamics increases as the morphodynamic conditions of the beach become more reflective. This pattern is associated with the tendency of dissipative beaches to smooth the action of wave storms, with most of the wave force dissipating in the surf zone before reaching the intertidal zone, while reflective beaches experience the full force of waves breaking directly on the intertidal zone (Short \& Wright 1983, Short 1996).

Erosion events could have drastic effects on sandy beach populations, such as mass mortality (e.g., McLusky et al. 1975) and local extinctions (Jaramillo et al. 1978). Thus, erosion-accretion dynamics may also play a role in the reduction of species along the morphodynamic gradient. 


\section{Organic matter availability}

McLachlan (1983) and Brown \& McLachlan (1990) suggested that because of its circulation pattern (i.e. cell circulation), phytoplankton could be retained in the surf zone of dissipative beaches, improving their primary productivity and the availability of organic matter. The results obtained here do not support this hypothesis, since neither the concentration of POM in the water nor the content of organic matter in the sediment were associated with the morphodynamic condition of the beaches. However, this conclusion is only valid for the morphodynamic range covered by the present study. It is important to bear in mind that central Chile lacks fully dissipative beaches.

\section{The 'multicausal environmental severity' hypothesis}

On the basis of a 2 yr study, 3 environmental gradients associated with changes in beach morphodynamics were found. Swash frequency and velocity increased, the grain size of the sediment became coarser, and the erosion-accretion dynamics became more intense as morphodynamic conditions changed from dissipative to reflective extremes. These 3 factors are physically interrelated, and linked with beach morphodynamics; however the discussion in the previous subsections suggests that they could have independent influences on different biological processes or species.

Thus, as changes in swash climate covary with changes in grain size and erosion-accretion dynamics, and given that cause-effect pathways between these factors and biological processes of the beach macrofauna are likely, I propose that these 3 environmental factors are capable of affecting the distribution of species along the morphodynamic gradient, and suggest that the reduction in species towards the reflective extreme are caused by increasing environmental severity generated by the sum of the independent effects of at least these 3 physical variables. This proposal constitutes the hypothesis of 'multicausal environmental severity'.

Contrary to the 'swash exclusion hypothesis' of McLachlan et al. (1993), this hypothesis agrees with the great interspecific variability in the life history and ecological traits of sandy beach communities, since it admits that species with different characteristics could be controlled by different limiting factors. The hypothesis of multicausality, which includes the swash exclusion hypothesis, provides a more general and flexible framework in which to investigate the biological processes and mechanisms underlying the wellknown relationship between species richness and beach morphodynamics.
For example, swash dynamics may be the key determining factor for organisms that live in the mid-low intertidal and have a poor capacity to swim or/and burrow, such as some species of molluscs (see McLachlan et al. 1995) and polychaetes. But swash climate would be less important for fast burrowers and good swimmers like the anomuran crab Emerita analoga, which is capable of sustaining large populations across a wide spectrum of swash-climate conditions (Brazeiro 1999b). For species living in the high intertidal zone, such as talitrid amphipods, swash climate does not seems to be the key factor either (Brazeiro 1999b, Gómez \& Defeo 1999).

Testing this hypothesis or that of McLachlan et al. (1993) is very difficult because it is very difficult to separate the individual effects of the factors concerned. The natural co-linearity among the physical variables constrains in situ attempts to identify the limiting factors. The situation is stressed by the difficulty to perform field experiments on exposed sandy beaches. However, laboratory experiments and statistical methods are 2 possible approaches, whereby the effect of each variable could be tested by removing the effects of the other variables.

Acknowledgements. This study is part of A.B.'s PhD thesis, carried out at the Departamento de Ecología, Pontifica Universidad Católica de Chile. I thank my thesis tutors, Dr Juan Carlos Castilla and Dr Pablo Marquet, for their ideas, constructive comments and advice during the early version of the manuscript. I also thank Dr Omar Defeo, Dr Luis Giménez and 4 anonymus revisors for their critical reading and useful comments. Oliver Lizana, jointly with Jovana Vilches, Stephan Gelcich, Cristián Miranda and Andrés Caro, made the fieldwork less hard and tedious. I also thank Malva Uribe and Paola Pedreros ('the Formalin girls') for laboratory assistance, and my brother 'Juanchi' for the linguistic revision of the manuscript. Financial support from FONDECYT No. 2970077 (Chile).

\section{LITERATURE CITED}

Alexander RR, Stanton RJ, Dodd JR (1993) Influence of sediment grain size on the burrowing of bivalves: correlation with distribution and stratigraphic persistence of selected neogene clams. Palaios 8:289-303

Araya-Vergara JF (1986) Toward a classification of beach profiles. J Coast Res 2:159-165

Bell EC, Denny MW (1994) Quantifying 'wave exposure': a simple device for recording maximum velocity and results of its use at several field sites. J Exp Mar Biol Ecol 181: 9-29

Borzone CA, Souza JRB, Soares A (1996) Morphodynamics and tropical macrofaunal structure. Rev Chil Hist Nat 69: 565-577

Brattstrom H, Johanssen A (1983) Ecological and regional zoogeography of the marine benthic fauna of Chile. Sarsia 68:289-339

Brazeiro A (1999a) Community patterns in sandy beaches of 
Chile: richness, composition, distribution and abundance of species. Rev Chil Hist Nat 72:99-111

Brazeiro A (1999b) Patrones comunitarios en ensambles de macroinvertebrados intermareales de playas arenosas expuestas de Chile: exploración de procesos y mecanismos subyacentes. PhD thesis, Pontificia Universidad Católica de Chile, Santiago

Brazeiro A, Defeo O (1996) Macrofauna zonation in microtidal sandy beaches: is it possible to identify patterns in such variable environments? Estuar Coast Shelf Sci 42:523-536

Brown AC (1983) The ecophysiology of sand beach animals: a partial review. In: McLachlan A, Erasmus T (eds) Sandy beaches as ecosystems. W Junk, The Hague, p 575-605

Brown AC, McLachlan A (1990) Ecology of sandy shores. Elsevier, Amsterdam

Castilla JC, Steinmiller DK, Pacheco CJ (1998) Quantifing wave exposure daily and hourly on the intertidal rocky shore of central Chile. Rev Chil Hist Nat 71:19-25

Defeo O, Jaramillo E, Lyonnet A (1992) Community structure and intertidal zonation of the macroinfauna on the atlantic coast of Uruguay. J Coast Res 8:830-839

Defeo O, Brazeiro A, de Alva A, Riestra G (1997) Is sandy beach macroinfauna only physically controlled? Role of substrate and competition in isopods. Estuar Coast Shelf Sci 45:453-462

Emery KO (1938) Rapid method of mechanical analysis of sand. J Sediment Petrol 8:105-111

Emery KO (1961) A simple method of measuring beach profiles. Limnol Oceanogr 6:90-93

Fonseca T, Farias M (1987) Estudio del proceso de surgencia en la costa chilena utilizando percepcion remota. Invest Pesq (Chile) 34:33-46

Gibbs RJ, Matthews MD, Link DA (1971) The relationship between sphere size and settling velocity. J Sediment Petrol 41:7-18

Gómez J, Defeo O (1999) Life history of the sandhopper Pseudorchestoidea brasiliensis (Amphipoda) in sandy beaches with contrasting morphodynamics. Mar Ecol Prog Ser 182:209-220

Jaramillo E (1987) Community ecology of Chilean sandy beaches. PhD dissertation, University of New Hampshire, Durham, SC

Jaramillo E, McLachlan A (1993) Community and population response of the macroinfauna to physical factors over a range of exposed sandy beaches in south-central Chile. Estuar Coast Shelf Sci 37:615-624

Jaramillo E, Croker RA, Hatfield EB (1978) Long-term structure, disturbance, and recolonization of macroinfauna in a New Hampshire sandy beach. Can J Zool 65:3024-3031

Jaramillo E, McLachlan A, Dugan JE (1995) Total sample area and estimates of species richness in exposed sandy beaches. Mar Ecol Prog Ser 119:311-314

McArdle SB, McLachlan A (1991) Dynamics of the swash zone and effluent line on sandy beaches. Mar Ecol Prog Ser 76:91-99

Editorial responsibility: Otto Kinne (Editor),

Oldendorf/Luhe, Germany
McArdle SB, A McLachlan (1992) Sand beach ecology: swash features relevant to the macrofauna. J Coast Res 8: 398-407

McLachlan A (1983) Sandy beach ecology: a review. In: McLachlan A, Erasmus T (eds) Sandy beach as ecosystems. W Junk, The Hague, p 321-380

McLachlan A (1990) Dissipative beaches and macrofauna communities on exposed intertidal sands. J Coast Res 6: $57-71$

McLachlan A (1996) Physical factors in benthic ecology: effects of changing sand particle size on beach fauna. Mar Ecol Prog Ser 131:205-217

McLachlan A, Jaramillo E (1995) Zonation on sandy beaches. Oceanogr Mar Biol Annu Rev 33:305-335

McLachlan A, Wooldridge T, Dye AH (1981) The ecology of two sandy beaches in southern Africa. S Afr J Zool 16: $219-231$

McLachlan A, Jaramillo E, Donn TE, Wessels F (1993) Sandy beach macrofauna communities and their control by the physical environment: a geographical comparison. J Coast Res 15:27-38

McLachlan A, Jaramillo E, Defeo O, Dugan J, de Ruyck A, Coetzee P (1995) Adaptation of bivalves to different beach types. J Exp Mar Biol Ecol 187:147-160

McLachlan A, Ruyck A, Hacking N (1996) Community structure on sandy beaches: patterns of richness and zonation in relation to tide range and latitude. Rev Chil Hist Nat 69: 451-467

McLusky DS, Nair SA, Stirling A, Bhargava R (1975) The ecology of a Central West Indian beach, with particular reference to Donax incarnatus. Mar Biol 30:267-276

Santelices B (1991) Littoral and subtidal communities of continental Chile. In: Mathieson AC, Nienhuis PH (eds) Intertidal and littoral ecosystems. Elsevier, Amsterdam, p 347-369

Seward-Thompson B, Hails J (1973) An appraisal on the computation of statistical parameters in grain size analysis. Sedimentology 11:83-98

Short AD (1996) The role of wave height, period, slope, tide range and embaymentisation in beach classifications: a review. Rev Chil Hist Nat 69:598-604

Short AD, Wright LD (1983) Physical variability of sandy beaches. In: McLachlan A, Erasmus T (eds) Sandy beaches as ecosystems. W Junk, The Hague, p 133-144

Strub PT, Mesias JM, Montecino V, Rutllant J, Salinas S (1998) Coast ocean circulation off western South America. In: Robinson AR, Brink KH (eds) The Sea Vol II. The global coastal ocean. John Wiley \& Sons, New York, p 273-313

Yannicelli B (1999) Zonación de Excirolana armata Dana Excirolana brazilienis Richardson (Isopoda: Cirolanidae) en playas arenosas micromareales: efectos de los ritmos de actividad, velocidad de enterramiento, y capacidad natatoria. MSc thesis, Facultad de Ciencias, Universidad de la República, Montevideo

Submitted: April 4, 2000; Accepted: May 8, 2001

Proofs received from author(s): December 10, 2001 